\title{
Product diversification as the impact of covid 19 on seafood-based culinary businesses
}

\author{
Hartati $^{1,{ }^{*}}$, Ahmad Muhlis Nuryadi ${ }^{1}$, Sitti Rosmalah $^{1}$, Muhammad Nur $^{1}$, Asriani $^{1}$ and \\ Muhammad Rais $^{2}$ \\ ${ }^{1}$ Agribusiness Study Program, Faculty of Agriculture, Universitas Muhammadiyah Kendari, Kendari, \\ Sulawesi Tenggara, Indonesia \\ ${ }^{2}$ Fisheries Resources Study Program, Faculty of Fisheries and Marine Science, Universitas \\ Muhammadiyah Kendari, Kendari, Sulawesi Tenggara, Indonesia
}

\begin{abstract}
Covid 19 encourages creative business actors to produce product diversification with very diverse menu variations. The purposes of this study are to: 1) analyze product diversification during the pandemic, 2) analyze the trigger factors for product diversification creativity. Respondents consisted of 56 people who were determined based on the criteria: 1) providing seafood menus, 2) diversifying products. The research was conducted for three months from September to December 2020 in Kendari by conducting interviews with respondents. Data were analyzed using description analysis, tabulation, Likert scale and multiple regression statistics to answer the research objectives. It is suspected that the triggering factors for product diversification during the COVID-19 pandemic are 1) competitiveness, 2) sustainability, 3) additional menus, 4) changes in atmosphere, and 5) customer trust. The results showed that product diversification occurred due to the pressure of the COVID-19 pandemic so that respondents should do anything in their power to survive while minimizing losses. This study concludes that the COVID-19 pandemic has encouraged the birth of new and more varied product Significant competitiveness, sustainability, additional menus and customer trust have a real influence on product diversification.. Meanwhile, the change of atmosphere has no significant effect on the diversification of production.
\end{abstract}

\section{Introduction}

Seafood culinary is currently in great demand by Kendarinese people, as it is identical to the tastes Kendarinese culinary preference who are used to consuming various kinds of fish. This is owing to the fact that Kendari is a capital city situated along coastal area consisting of bays. The land area of Kendari is $295.89 \mathrm{~km}^{2}$ or $0.78 \%$ of the land area of Southeast Sulawesi Province. Since 2015 a bridge has been built to connects Kendari with Abeli District, and quite recently the additional new bridge with a length of 1.34 kilometers and a

*Corresponding author: hartati@umkendari.ac.id 
width of $20 \mathrm{~m}$ is completed and has been used by Kendarinese people since October 2020 $[1]$.

In addition, along Kendari Bay there are food stalls serving various culinary dishes typical of Kendari, including seafood, a bay area popularly known by locals as "Kendari Beach". The city of Kendari has been very quiet and reserved since the COVID-19 pandemic hit for the first time, precisely from March to June 2020. This condition greatly disrupted the economy of Kendari. Most of the food stalls are closed, including seafood culinary stalls. The condition of Kendari with the distribution of its culinary food stalls from satellite imagery can be seen in Figure 1.

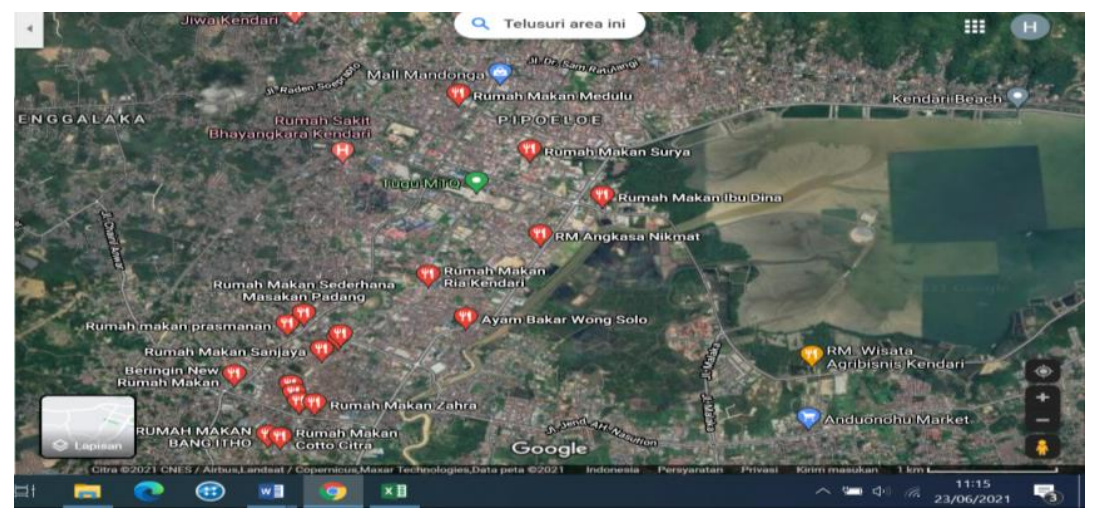

Fig. 1. Distribution of food stalls in Kendari as seen from Satellite Imagery

This condition evidently impacted on various fields, including the culinary businesses. The impacts diverged into positive and negative impacts. For the positive side, there is a desire and hope to stay afloat and be able to get out safely from the risks posed by Covid19. Various ways are pursued by business actors to be able to run their business sustainably. One of the ways is to diversify culinary products. Activities are still taking place online due to the COVID-19 pandemic [2]. Socio-preneurs during the COVID-19 pandemic can act as agents of change and create solutions for sustainable development (SDGs) [3].

This product diversification's creativity appears in conjunction with the Covid-19 pandemic to persist business actors to survive. Thus, the form of product diversification in seafood restaurants is carried out to improve: 1) competitiveness, 2) sustainability, 3) additional menus, 4) atmosphere change, and 5) customer trust. Su, at al. (2017) stated that there is a positive attitude with the services and product diversification offered on tourism in China. Furthermore, Silva, at al. (2016) stated in the results of his research that the adult consumers tend to have personal characteristics about product and service assessments. There is a positive attitude with the service and product diversification offered to tourism in China [4]. Adult consumers tend to have personal characteristics about product and service ratings [5].

\section{Research methods}

The population in this study consisted of 213 seafood culinary business actors, and 56 entrepreneurs were used as respondents. This is based on the criteria for seafood culinary business actors who diversify products during the covid 19 pandemic. The pandemic era is not an obstacle for people to carry out business activities [2].

The study used primary data and secondary data. Primary data was obtained from respondents through interviews and direct observation at the research site, secondary data 
was obtained from several journals, e-books and the Central Statistics Agency (BPS) of Kendari City. The secondary data obtained were reprocessed based on needs.

Product diversification is a respondent's decision with several goals or expectations. The purpose of product diversification becomes a variable in this study. The objectives of product diversification are 1) competitiveness, 2) business sustainability, 3) additional menus, 4) changes in atmosphere and, 5) customer trust. The five variables will be analyzed using several analytical tools.

The research data was processed using descriptive analysis (tabulation and percentage), weighted using a Likert scale. Likert scale is used to measure attitudes, opinions and perceptions of a person or group of people about social phenomena [6]. Then, multiple regression analysis was used with the statistical analysis method of IBM Statistical Product and Service Solution (SPSS) software version 20 [7]. The multiple linear regression analysis is as in the following formula:

Information :

$$
Y=\alpha+\beta 1 \times 1+\beta 2 \times 2+\beta 3 \times 3+\beta 4 \times 4+\beta 5 \times 5+\mathrm{e}
$$

$Y=$ Product diversification

$x 1=$ Competitiveness

$x 2=$ Continuity

$x 3=$ Additional menu

$x 4=$ Mood change

$x 5=$ Customer trust

\section{Results and discussion}

\subsection{Characteristics of Research Sites}

Data on business actors in Kendari City (Mandonga, Kadia Poasia, Kambu and Kendari based on the criteria of intermediate merchant and small merchant are 1,279 business actors. With details of medium merchant as many as 685 business actors and 1279 small merchant. As for details of business actors in Kendari City based on five districts/cities can be seen in Figure 2.

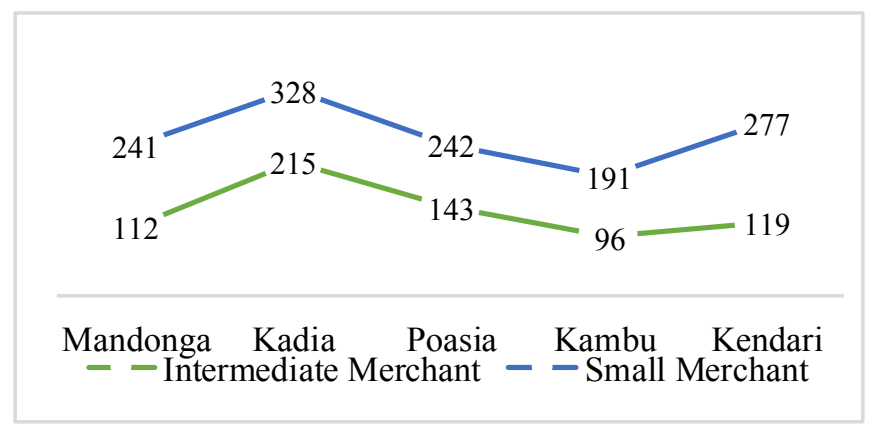

Fig. 2. Distribution of merchant in Kendari City

The distribution of business actors is the number of business actors in general with a mapping based on medium and small business actors. The number of culinary business actors is 213 business actors, and as many as $56(11 \%)$ are business actors who diversify products. This can be seen according to Figure 3 . 


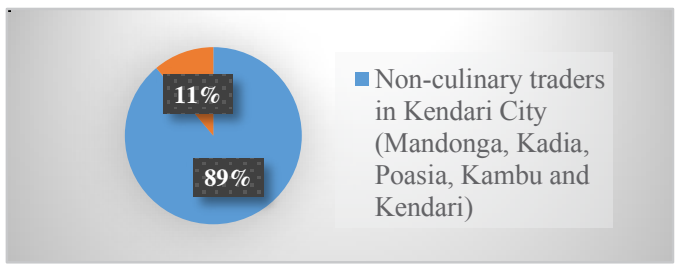

Fig. 3. Percentage of merchant in Kendari City in 2020

Culinary business actors who diversify products aim to increase competitiveness and business sustainability, but most business actors have not diversified products, this is due to the unclear condition of the COVID-19 pandemic, when it will end. There is still negative sentiment from business actors as a result of the COVID-19 impact.

\subsection{Respondent's identity}

The identity of the respondent influences the decision taken by the respondent to diversify the product. The identity of the respondents in this study which was observed consisted of education level, age, work experience and gender. The identity of the respondents can be seen in Figure 4.

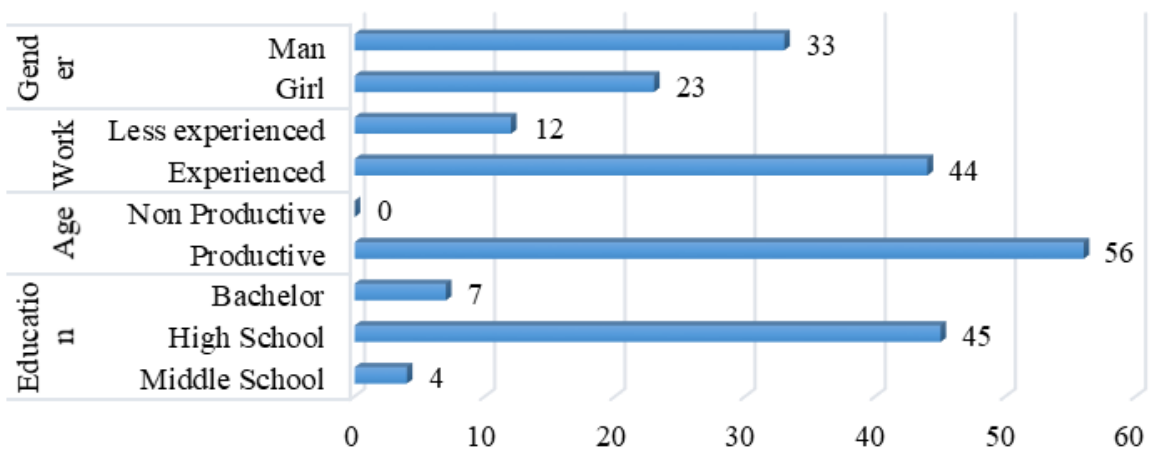

Fig. 4. Identity of respondents

The identity of the respondents in this study showed that most of the respondents had high school education as many as 45 people $(80 \%)$ with a productive age of 44 people $(76 \%)$ and all respondents 56 people $(100 \%)$ had culinary business experience. The gender of the respondents consisted of 23 women (41\%) and 33 men (59\%). Respondent's gender significantly influences the choice of seafood and motivation to buy [8]

Product diversification is the development of products that are designed according to consumer needs during the COVID-19 pandemic. Product design consists of adding flavors to dishes made from oranges according to the needs of the COVID-19 pandemic. This is done by respondents so that products are competitive and sustainable both during the COVID-19 pandemic and during the COVID-19 pandemic. The pandemic is gone on the motherland of Indonesia. The food products offered vary from fresh food to healthier processed foods [9]. Seafood culinary business can be sustainable by properly labeling and selecting types of marine fish that can be recommended as healthy food for consumers [10]. Product design driven by the COVID-19 pandemic conditions gave birth to new, more varied products. Agro-based industries affected by the Covid-19 pandemic must be given the highest priority, so that they can rise up and keep trying [11]. The situation during the Covid-19 pandemic has an impact on social, cultural and economic life [3]. 


\subsection{Data analysis}

The research was analyzed using the statistical analysis method of IBM Statistical Product and Service Solution (SPSS) software version 20. The data was processed first through tabulation and weighting on the Likert scale using complete data. Furthermore, the data is processed using multiple regression analysis.

The data of this study indicate that all data on the dependent variable (product diversification) and variables entered (Customer trust, Competitiveness, Additional menu, Atmosphere change, Sustainability) were included in this study (no variables were removed), so the method used was single. step(enter) not stepwise.

Tabel 1. Model Summary R Square dan Standart error of the estimate

\begin{tabular}{|l|l|r|r|c|}
\hline \multicolumn{5}{|c|}{ Model Summary $^{\mathbf{b}}$} \\
\hline Model & $\mathrm{R}$ & \multicolumn{1}{|c|}{ R Square } & Adjusted R Square & Std. Error of the Estimate \\
\hline 1 & $.949^{\mathrm{a}}$ & .900 & .890 & 1.295 \\
\hline
\end{tabular}

a. Predictors: (Constant), Customer trust, Competitiveness, Additional menu, Atmosphere change, Sustainability.

b. Dependent Variable: Product diversification

The number of $R$ square (correlation coefficient) in Table 1 is 0.900 . This value is the square of the value of $\mathrm{R}=0.949$. $\mathrm{R}$ square indicates that the product diversification variable can be explained by variables Customer trust, Competitiveness, Additional menu, Atmosphere change and Sustainability by $90 \%$ while $10 \%$ is explained by other variables outside the model. The value of $\mathrm{R}$ square is in the range of numbers 0 to 1 . The smaller the value of $\mathrm{R}$ square, the weaker the relationship between variables. The results of this study indicate that the value of $\mathrm{R}$ square is 0.900 , close to the value of 1 , so it can be said that there is a strong relationship between product diversification and variables (Customer trust, Competitiveness, Additional menu, Atmosphere change and Sustainability). Product diversification has a positive effect on food security [12]. Baldwin (2017) Japan is a country that is very focused on its culinary authenticity [13]. In Karangtengah Village, Indonesia, the development of agro-tourism with a strategy based on local wisdom through master plan planning and potential optimization [14]. The increasing popularity of traditional Japanese foods such as sashimi and sushi made from seafood tends to increase the incidence of anisakiasis in many countries [15]. This is the impact of the way Japanese cuisine is presented with processed raw fish.

Based on the two research results, this condition is an opportunity or challenge to diversify products and or maintain the original menu of processed fish (grilled fish) for business actors in Indonesia. It is necessary to develop a diversification of processed food, not only focusing on traditional products [16]. Technology development aims to improve product quality [17]. Performance improvement is directed at high value added products, technology investment, resource saving, energy saving investment, new technology, management system improvement, and certification [18]. The regression equation used, can it predict the model? the significance value of the model can be used to predict the model. This can be seen in Table 2 .

Table 2. ANOVA model on multiple regression product diversification

\begin{tabular}{|l|l|r|r|r|r|r|}
\hline \multicolumn{7}{|c|}{ ANOVA $^{\mathbf{a}}$} \\
\hline \multirow{2}{*}{ Model } & Sum of Squares & df & Mean Square & F & \multicolumn{1}{c|}{ Sig. } \\
\hline \multirow{3}{*}{1} & Regression & 756.078 & 5 & 151.216 & 90.112 & $.000^{\mathrm{b}}$ \\
\cline { 2 - 8 } & Residual & 83.904 & 50 & 1.678 & & \\
\cline { 2 - 8 } & Total & 839.982 & 55 & & & \\
\hline
\end{tabular}

a. Dependent Variable: Product diversification 
b. Predictors: (Constant), Customer trust, Competitiveness, Additional menu, Atmosphere change, Sustainability

The results of the regression analysis in Table 2 show that the calculated $F$ value is 90,112 with Sig. of 0.000 . The significance value of 0.000 is smaller than 0.05 , so this regression model can be used to predict product diversification or it can be said that Competitiveness, Sustainability, Additional menu, Customer trust and Atmosphere change, simultaneously have a significant effect on product diversification.

The sustainability of the culinary business is the biggest hope of the respondents in this study. One of the ways that respondents do to achieve business sustainability is to diversify products. Jamal, at al. (2018) stated in the results of his research that partially, the dimensions of commitment, and communication have a positive and significant effect on customer retention. The three largest seafood markets in the world, the EU, Japan, and the United States, have high growth in seafood trade [19]. The level of productivity will be related to technology adoption and choice to face risks, both production and marketing [20]. Companies must find solutions to overcome their weaknesses, such as the lack of technology use [21].

Competitiveness is the goal of product diversification. The varied products are expected to provide space for business actors to be competitive. On the other hand, adding a menu to the menu is a business development process. Technology is needed to diversify high-quality products [17]. Environmentally friendly principles encourage the development of high quality products [22].

In this study, simultaneously Competitiveness, Sustainability, Additional menu, Customer trust and Atmosphere change significantly affect product diversification. However, separately, it turns out that the predictor variables Competitiveness, Sustainability, Additional menu, Customer trust and Atmosphere change have no significant effect. The influence of each variable in this study can be seen in Table 3.

Table 3. Multiple regression analysis of product diversification

\begin{tabular}{|c|c|c|c|c|c|c|c|}
\hline \multicolumn{8}{|c|}{ Coefficients $^{\mathrm{a}}$} \\
\hline \multirow[t]{2}{*}{ Model } & \multicolumn{2}{|c|}{$\begin{array}{l}\text { Unstandardized } \\
\text { Coefficients }\end{array}$} & \multirow{2}{*}{$\begin{array}{c}\text { Standardized } \\
\text { Coefficients }\end{array}$} & \multirow[t]{2}{*}{$\mathrm{t}$} & \multirow[t]{2}{*}{ Sig. } & \multicolumn{2}{|c|}{$\begin{array}{c}95,0 \% \text { Confidence } \\
\text { Interval for B }\end{array}$} \\
\hline & B & $\begin{array}{l}\text { Std. } \\
\text { Error }\end{array}$ & & & & $\begin{array}{l}\text { Lower } \\
\text { Bound }\end{array}$ & $\begin{array}{l}\text { Upper } \\
\text { Bound }\end{array}$ \\
\hline (Constant) & -.951 & 1.004 & & -.947 & .348 & -2.967 & 1.066 \\
\hline Competitiveness & 1.591 & .290 & .367 & 5.490 & .000 & 1.009 & 2.174 \\
\hline Sustainability & 1.047 & .356 & .243 & 2.944 & .005 & .333 & 1.762 \\
\hline Additional menu & .722 & .323 & .138 & 2.234 & .030 & .073 & 1.371 \\
\hline Atmosphere change & .621 & .346 & .145 & 1.795 & .079 & -.074 & 1.317 \\
\hline Customer trust & 1.203 & .293 & .242 & 4.102 & .000 & .614 & 1.792 \\
\hline
\end{tabular}

a. Dependent Variable: Product diversification

The results of the regression model analysis in Table 3 show that of the five variables used as predictors to predict product diversification, four variables (Competitiveness, Sustainability, Additional menu, Customer trust) have a significant effect on product diversification with respective significances of $0.000,0.005,0.030$ and 0.000 . While the variable atmosphere change has no real effect on product diversification with a significance of 0.079 .

One of the product diversification variables that affect this research is business sustainability. So it can be said that product diversification is one way to increase customer retention. Customer retention is maintaining a sustainable business relationship with customers in the long term. Jamal, at al. (2018) Efforts are needed to improve the quality of service speed through increasing customer retention in the seafood culinary business [23]. 
One of the causes of impediments to sustainable development in the Ukrainian region is weak innovation activity [24].

Products with high innovation can increase the company's competitiveness. Business development can be done through labeling and protecting products, so that customers' trust can be obtained through menu additions. A third of seafood was mislabeled and more than a quarter of the samples had mercury levels above the US EPA recommended limit (300 $\mathrm{ng} / \mathrm{g} \mathrm{ww}$ ). In addition, $30 \%$ of the samples are threatened and protected species [10]. In this study, the atmosphere change variable is a variable that has no significant effect on product diversification. The multiple regression model by removing the variable Atmosphere change, the results of the analysis can be seen in Table 4 .

Table 4. Multiple regression analysis of product diversification without variable atmosphere change

\begin{tabular}{|c|c|c|c|c|c|c|c|}
\hline \multicolumn{8}{|c|}{ Coefficients $^{\mathrm{a}}$} \\
\hline \multirow[t]{2}{*}{ Model } & \multicolumn{2}{|c|}{$\begin{array}{l}\text { Unstandardized } \\
\text { Coefficients }\end{array}$} & $\begin{array}{l}\text { Standardized } \\
\text { Coefficients }\end{array}$ & \multirow[t]{2}{*}{$\mathrm{t}$} & \multirow[t]{2}{*}{ Sig. } & \multicolumn{2}{|c|}{$\begin{array}{l}95.0 \% \text { Confidence } \\
\text { Interval for B }\end{array}$} \\
\hline & B & $\begin{array}{l}\text { Std. } \\
\text { Error }\end{array}$ & Beta & & & $\begin{array}{l}\text { Lower } \\
\text { Bound }\end{array}$ & $\begin{array}{l}\text { Upper } \\
\text { Bound }\end{array}$ \\
\hline (Constant) & -1.101 & 1.022 & & -1.077 & .027 & -3.153 & .951 \\
\hline Competitiveness & 1.749 & .282 & .403 & 6.199 & .000 & 1.183 & 2.316 \\
\hline Sustainability & 1.319 & .329 & .306 & 4.010 & .000 & .658 & 1.979 \\
\hline Additional menu & .790 & .328 & .151 & 2.409 & .020 & .132 & 1.448 \\
\hline Customer trust & 1.349 & .288 & .271 & 4.685 & .000 & .771 & 1.927 \\
\hline
\end{tabular}

a. Dependent Variable: Product diversification

The results of the analysis in Table 4 by removing the variable Atmosphere change show that product diversification is obtained by a regression model that has a significant effect. Competitiveness, Sustainability, Additional menu and Customer trust are the impetus for business actors to diversify products during the covid 19 pandemic. Atmosphere change is thought to have no real impact because atmosphere change is a new habit that must be carried out.

Product diversification from new menu variants is the key to business development offering products that adapt to the conditions of covid 19. Increased immunity is the reason for the new menu variant in product diversification. The COVID-19 pandemic has made people aware to follow a healthy lifestyle. Included in choosing the food menu. The food products offered vary from fresh food to processed food as a form of business development [9]. Increasing consumption of seafood can be a goal of overall product diversification. The consumption of seafood in Poland is regularly increasing, although it still remains at a relatively low level compared to consumption of processed fish products [8]. Consumer ecommerce $(\mathrm{C} 2 \mathrm{C})$ product marketing is a key factor in business development [9].

Competitiveness of products during the pandemic as an effort for business continuity and sustainability. Food management strategies need to be addressed, strived for, guaranteed availability and distribution [25]. Oglend, et al. (2019) Larger firms with greater diversification of trading partners have lower risk [26]. Business continuity and customer trust are variables that have a significant impact on product diversification. Customer trust drives increased purchasing power. Increased purchasing power contributes to the development of new businesses [27]. Business development will have an influence on the sustainability of development. Istiqomah, et al. (2021) Business management must pay attention to sustainable development [28]. 


\section{Conclusions}

Product diversification is one of the goals of business actors to survive. The purpose of product diversification as a predictor variable (Competitiveness, Sustainability, Additional menu, Customer trust and Atmosphere change) in this study. The COVID-19 pandemic has encouraged the birth of new, more varied products. Competitiveness, Sustainability, Additional menu and Customer trust are variables that have a significant effect on product diversification, while Atmosphere change has no significant effect on product diversification. This study recommends for business actors to carry out product diversification.

\section{Reference}

1. Badan Pusat Statistik (BPS) Kota Kendari 2020

2. M.I. Rosyidi, A. H. Purwantini, L. Muliawanti, B.C. Purnomo, A.Widyanto, E3S Web of Conferences IConARD 2020232 (2021)

3. W.B. Priatna, H. Santoso, M.G. Moenawar, E3S Web of Conferences IConARD 2020 $232(2021)$

4. M. M Su, G. Wall, S. Wang, Island Studies Journal, 12, 127 (2017)

5. F. Quevedo-Silva, D.O. Lima-Filho, M.B.B. Fagundes, British Food Journal (2016)

6. Sugiyono. Metode Penelitian Pendidikan Pendekatan Kuantitatif,. Kualitatif, dan R\&D. Bandung: Alfabeta (2013)

7. S. Santoso, SPSS 20 from essential to expert skills (2014)

8. Ż. Sikorska, E.W. Piesik, A. J. Agribus. Rural Dev, 3 (2016)

9. H. Akhmad and S. Pratolo, E3S Web of Conferences IConARD 2020232 (2021)

10. D. Bif, A. López-Mobilia, S. Kelez, D.A. Williams, M.M. Chumchal \& M. Weinburgh. Scientifc Reports | (2020)

11. A. Bidarti, E3S Web of Conferences IConARD 2020, 232 (2021)

12. R.O. Akrasi1, P.N Eddico, R. Adarkwah, Journal of Food Security 8 (2020)

13. W. Baldwin, Journal of Tourism, Hospitality \& Culinary Arts (JTHCA) 9 (2017)

14. Sriyadi, H. Akhmadi, A. Yekti, E3S Web of Conferences IConARD 2020232 (2021)

15. K. Furuya, H. Nakajima, Y. Sasaki, Y. Urita, Nigerian Journal of Clinical Practice 21 (2018)

16. M. Lintang, P. Layuk, Sudarti, J. Sondakh, E3S Web of Conferences IConARD 2020 $232(2021)$

17. M.G. Zagoruyko, M.Y. Chaplygin, and S.A. Davydova, E3S Web of Conferences ICMTMTE 2020193 (2020)

18. V. Lavrenenko1, H. Yanhol, B. Tishkov, E3S Web of Conferences ICSF 2021280 (2021)

19. R. E. Dahl \& E. Jonsson, Journal of Commodity Markets (2017)

20. H.S.P. Rahayu, M. Dewi, T. Febrianti, E3S Web of Conferences IConARD 2020232 (2021)

21. I. Fatmawati, S.A. Bestari, R. Rostiani, E3S Web of Conferences IConARD 2020232 (2021) 
22. T.E. Marinchenko, E3S Web of Conferences ICMTMTE 2020193 (2020)

23. Jamal, A.T. Nifita and G.Y. Rosyid, Journal of Business Studies and Management Review (JBSMR) 2, 53 (2018)

24. V. Babenko, L. Zomchak, M. Nehrey, E3S Web of Conferences ICSF 2021280 (2021)

25. L. Setiartiti, E3S Web of Conferences IConARD 2020232 (2021)

26. A. Oglend, H.M. Straume, J Futures Markets (2019)

27. A. Avadí, I. Vázquez-Rowe, A. Symeonidis, E. Moreno-Ruiz, The International Journal of Life Cycle Assessment (2019)

28. N. Istiqomah, N.A. Yunikawati, E.Y. Puspasari, M.A. Jabbar, E3S Web of Conferences IConARD 2020232 (2021) 